\title{
The Epistemic Indispensability of Understanding in Historiography
}

\author{
Fons Dewulf
}

Research Foundation Flanders - Ghent University

fons.dewulf@ugent.be

(0032) 092643968

\section{Abstract}

In this paper I argue that understanding is an indispensable epistemic procedure when historians use texts as evidence. On my account understanding installs a norm that determines what kind of event or object a texts is evidence of. Historians can debate which norms should govern a body of texts, and if they reach consensus, they can use that body of texts as an empirical constraint over their historical claims. I argue that texts cannot perform this constraining function without understanding - it is thus indispensable. In order to argue for this position I first discuss two existing accounts of textual evidence in analytic philosophy of science by Kosso and Hurst. Both defend a coherentist position. I show that their coherentist position is flawed by applying it to the famous case of Lucien Febvre's argument that François Rabelais was not an atheist. I show that a coherence between texts leaves the debate concerning Rabelais' religious beliefs underdetermined, even though this should not be necessary. I argue that my account of understanding better captures Febvre's actual reasoning with texts. In the final section of the paper I show that the two most famous accounts of understanding in analytic philosophy by Hempel and Taylor ignore either the epistemic indispensability of understanding, or the actual success of evidentiary reasoning in the historical sciences that was enabled by understanding.

Keywords

Understanding, Evidence, Historiography, History, Lucien Febvre, Coherentism 


\section{Introduction}

Certain questions about the past can only be answered by using various types of texts as evidence. Ascertaining whether a $16^{\text {th }}$ century novelist was an atheist or not, can only rely on his writings and the contemporary testimonies about the author or his works. Similarly, the question whether certain Amazonian tribes actually performed cannibalistic rituals in the $16^{\text {th }}$ century can only be answered through textual reports of these rituals. ${ }^{1}$ Or, in order to determine whether Captain Cooke was really considered to be the Hawaiian God Lono during his final days in Hawaii, one can only use the textual reports of the events and of Cooke's previous relation to Hawaiian society. ${ }^{2}$ In all these cases historians are faced with a body of texts that should be used as evidence to guide their account to the truth about past events, beliefs and societies. Many historians consider such questions worth pursuing, and think that they are solvable in principle based on the available textual evidence.

Often, however, historians disagree what exactly texts are evidence of. Such discussions among historians are interesting material for a philosophical investigation into the nature of textual evidence. In principle, textual materials from the vast archives of human endeavours should yield a similar body of evidence as observation and experimentation in the natural sciences. Unfortunately, philosophy of science lacks an extensive literature on the specific problems concerning textual evidence in historiography. This is a missed opportunity. A reflection on the specific nature of textual evidence might help philosophers to better understand the nature of evidence in general. Moreover, such a reflection could also aid historians in better grasping the possible avenues to reason through textual evidence.

In this paper I first summarize the only two existing accounts of textual evidence in analytic philosophy, namely by Kosso and Hurst. I, then, introduce a case study that will guide my analysis throughout the rest of the paper, namely Lucien Febvre's argument that François

1 Among historians there has been a considerable debate over the testimony of cannibalism amongst the Tupinambá that was given by $16^{\text {th }}$ century German sailor Hans Staden. Some have argued that Staden's account should be read as a trustworthy testimony of cannibalist rituals (Forsyth and Staden 1985; Whitehead 2000), while others have emphasized the commercial motives of Staden's sensational account and its related untrustworthiness (Schmolz-Haberlein and Haberlein 2001).

2 The case of the apotheosis of Captain Cooke is important, as it also determines the image of Cooke and his relation as a British imperialist towards Hawaiians. The case is especially interesting because historians can only rely on British reports of the events, and should thus try to refrain from understanding those events solely from the viewpoint of the reporting persons (Obeyesekere 1997). 
Rabelais was not an atheist. Based on my analysis of this case I point out that the analyses of Kosso and Hurst fail to account for the actual use of textual evidence by historians, because their accounts do not assign any epistemic function to the understanding of texts. I argue instead that an understanding of texts is epistemically indispensable in the assessment of textual evidence. In the final section of the paper I demonstrate that the two most famous accounts of understanding in analytic philosophy ignore either the epistemic indispensability of understanding (Hempel 1942), or ignore the actual success of evidentiary reasoning in the historical sciences that is made possible by understanding (Taylor 1971).

\section{A Coherentist Position on Evidence in History}

Peter Kosso introduced an account of how textual evidence in historiography can itself be justified. His main question is how textual evidence from the past can be deemed reliable and accurate (Kosso 1993, 1). “Any claim that can justify must also be justified.” (Kosso 1993, 6) He argues that textual evidence can be justified through four different avenues of corroboration (Kosso 1993, 7). The first and according to him most reliable avenue is a corroboration by independent material sources. For instance, the report of a solar eclipse can be checked through astronomical knowledge. The second avenue is corroboration from other independently written sources that state similar things as the text that is in need of justification. A third path assesses the reliability of the author of the text, his method and intentions when writing the text. The fourth, and most difficult path is purely internal criticism of a text. In this case a historian looks for inconsistencies or improbabilities within the text itself, and tries to isolate the doubtful passages. Kosso concludes that the accountability of evidence is mainly an internalist procedure: one mostly checks the reliability of textual evidence against other texts and there can be no checking against the events themselves (Kosso 1993, 12). This situation requires that the historian aims to attain maximal coherence between texts, and tries to attain a constant supply of new evidence to cohere with. "Continued coherence in a process of accumulating claims (more observations, more data, more texts read) adds credibility by surviving the increasing chances of failure." (Kosso 1993, 13)

A related coherentist account of historical evidence is given by Hurst (Hurst 1981). Hurst argues that all data descriptions of the historian should always fit within a narrative about the 
past. Data descpritions are “narrative-laden” (Hurst 1981, 278-279). Specifically, Hurst argues that every description of a datum entails a hypothesis. It supposes that the change it describes actually occurred. This, in turn, forces the historian to fit all his data descriptions and their related hypotheses into a coherent and consistent narrative (Hurst 1981, 281). For instance whether a text should be described as a message or as an aide memoire depends on the historian's narrative concerning the writer of the message, which in turn is related to other narratives about the period in general (Hurst 1981, 282). The historian starts from all kinds of physical objects, among others texts, and then builds up a consistent and coherent network of change-referring datum descriptions of that body of texts (Hurst 1981, 283). When faced with incoherence, the historian can change the datum description of an object, or change other data descriptions within the narrative. Similar to Kosso, Hurst believes that historians should be constantly on the lookout for more objects from the past and their related data-descriptions that fit the larger narrative or web of hypotheses which they defend. "It is a methodological requirement to seek out data whose discovery is predictable only on the basis of the one rather than the other narrative network." (Hurst 1981, 289) This way, the historian seeks progressive, maximal coherence and consistency between various webs of hypotheses about the past, all related to physical objects through data-descriptions. Hurst's inspiration for this forward-looking paradigm of historical research is Lakatos' ideas about progressive and degenerate research programs (Hurst 1981, 287).

Both Kosso and Hurst emphasize that textual evidence can only perform its epistemic function within a larger coherent web of other pieces of historical data. Thus, the evidence of any historical claim should always be linked to a larger network of evidence. In Kosso's account, the search for coherence is cashed out in four categories of corroboration of evidence, in different degrees of internalism. Hurst's account is less specific about the exact ways data descriptions as hypotheses should cohere within a network. Both accounts, however, strongly emphasize that historical evidence always operates within a larger network of evidence. All pieces of available evidence on the one hand need to cohere with each other, and on the other hand with possible future pieces of evidence.

\section{The Problem of 16th Century Unbelief}

In order to discuss the problems with a coherentist position about textual evidence, I introduce a case study which is taken from a highly influential historical work by Lucien 
Febvre. ${ }^{3}$ Febvre's book The problem of 16th century unbelief: the religion of Rabelais is both an ambitious overview of the evidence for unbelief in France during the first half of the $16^{\text {th }}$ century and a methodological reflection on the nature of evidence for unbelief. The book consists of two parts. The first part is directed against a thesis advanced by Abel Lefranc in the preface to his 1923 edition of the completed works of François Rabelais. Lefranc was a French historian of literature contemporary to Febvre who had claimed that Rabelais was one of the first in a long French, rationalist and atheist tradition. Febvre devotes the first part of the book to discrediting any possible piece of textual evidence supporting Lefranc's view. To this end, Febvre needed to disprove much of the evidence that Lefranc thought had accrued for the claim that Rabelais was an atheist. Febvre's assessment of the textual evidence concerning Rabelais' religious beliefs is still accepted by historians (Gauna 1992, 25-26). Because this part of Febvre's book explicitly brings the nature of textual evidence under scrutiny, I will go over it in more detail and use it throughout this paper as an exemplary account of the epistemic role of textual evidence in historiography.

The second part of Febvre's book contains a much stronger and still very controversial claim: Rabelais could not have been an atheist, because he lacked any theoretical language or metaphysical worldview to express such a belief. This claim, however interesting, brings with it central metaphysical questions about what it means to have a belief. Since it is not directly related to evidentiary problems and pushes itself deep into the realm of philosophy, I will not say anything else about it. My concern is solely with the function of textual evidence in historiography.

The evidence for Rabelais' unbelief, as it was set out by Lefranc, can be split up into two fields: the testimonies of Rabelais' contemporaries on his religious beliefs, which Febvre treats in the first book of part one and the ideas that Rabelais expressed in his literary works, which are treated by Febvre in the second book of part one. In both fields Lefranc thought he had found evidence for Rabelais' unbelief. Febvre scrutinizes every piece of text in great detail and tries to discredit this evidence. I will use two examples to show how Febvre proceeds. The first example is the accusation of Rabelais as an atheist by Calvin in 1550. This textual testimony seems like a very clear and convincing piece of evidence: Calvin as one of

3 More than 40 years after its original publication, Febvre's book was translated into English and it was hailed as a book that could still pose some of the most penetrating questions concerning $16^{\text {th }}$ century texts and our understanding of them (Kelley 1984; Wootton 1988). It is also one of the classics of the highly influential Annales school (Iggers 1997, 55-56). 
the most important theologians at that time surely knew what he was talking about and would not make such an accusation lightly. Febvre emphasizes the huge importance this text seems to have: "It is the text." (Febvre 1962, 125) Febvre, however, argues that we cannot take this to be evidence for Rabelais' unbelief, because such an accusation does not imply that Calvin had studied Rabelais' texts and concluded that he was an atheist, a denier of any deity. Febvre shows that an accusation of atheism was thrown around by almost everyone and against everyone between 1533 and 1550 in French literary and theological circles. If such an accusation should be taken as evidence of unbelief, we should believe that everyone was an unbeliever (Febvre 1962, 134). Before the accusation can be used as evidence of unbelief, it is important, according to Febvre, to understand it within the culture of reasoning that is particular to that era (Febvre 1962, 134). This understanding entails that the "mental tools" [outillage mentale] of that age should be taken into account: an accusation of atheism was more like an insult to someone that could be launched without much proof or rigour (Febvre 1962, 142). More than a precise statement of the true beliefs about a person, it was a sign of great differences in religious opinions between the historical actors. Thus, on Febvre's argument the textual accusation of Rabelais by Calvin is only evidence of resentment towards Rabelais from the side of Calvin.

Going over to the second field of evidence of Rabelais' unbelief, Febvre is confronted with a similar situation. In chapter XXX of his Pantagruel, Rabelais writes a resurrection scene that seems to mock the miraculous resurrection of Jaïre and Lazarus from the new testament. Mocking the miracles of Christ could be taken as clear evidence of an expression of unbelief. Here, Febvre's strategy again focuses on situating the text within its contemporary style of thinking or "mental tools" [outillage mentale]. In order to understand the text properly, Febvre claims that one needs to realize that the resurrection scene is foremost a reference to other similar resurrection scenes in a then popular genre of the chansons de gestes. Of course, it would still be a parody of a resurrection and remain suspicious (Febvre 1962, 203). Febvre, however, argues that the popular belief in miracles, which was widely spread in society, was exactly itself part of a controversy within Christianity: both Erasmus and Luther wanted to separate the faith in Christ from the popular belief in miracles. Again, whatever Rabelais' exact intentions were, it is very difficult to take the text in chapter XXX of Pantagruel as evidence of unbelief, given the fact that very strong believers themselves had great reservations against the popular belief in miracles. 
One of the central messages of Febvre's book concerns precisely the caution to directly treat texts as evidence for a historical claim. The historian should not take a text of an author as an isolated piece of evidence, and "just because a certain passage in his work fits in with the direction of one of our own modes of feeling, to decide that he fits under one of the rubrics we use today for classifying those who do or do not think like us in matters of religion." (Febvre 1962, 15; Febvre 1985, 5) Febvre warns his readers that texts in isolation do not yield any evidence for any historical claim. At most, a text that is considered in isolation by the historian will become an artefact of the categories of our thinking, but in no case can it be evidence for the thoughts of the historical actors themselves. ${ }^{4}$ This can also occur if many texts are treated in isolation, but taken together seem to comprise a large body of evidence, as it was with Lefranc's case for Rabelais' unbelief.

Nevertheless, Febvre explicitly believes texts can be used as evidence: they perform a constraint on the possible claims that a historian can make. This constraining function of textual evidence will, however, require the right kind of understanding or reading of the text. Even if the texts would be richer, the testimonies more talkative, and the confessions more detailed, the correct understanding of the texts would still be a necessary requirement (Febvre 1962, 15). ${ }^{5}$ The notion of "understanding" or "reading" of texts and other historical sources is completely absent from the accounts of Hurst and Kosso. As any good empiricist position, they exclude notions, such as understanding, that cannot be reduced to empirical evidence itself. If their accounts are compared with Febvre's argumentative strategy, this results in problems.

\section{The Epistemic Indispensability of Understanding}

The coherentist position of Kosso and Hurst entails that texts on themselves have no epistemic meaning. Their framework thus resembles a central norm of Febvre's evidentiary

4 A very similar warning can be found in Skinner's Meaning and Understanding in the history of ideas (Skinner 1969, 6). Skinner's problem is very similar to Febvre's: as an intellectual historian he reflects how the historian should assess textual sources of —in his case-early modern political theory.

5 In Skinner's article this point is given much attention: "the underlying assumption of this whole approachthat one should focus simply on the texts themselves, and study what each classic writer has to say about each given doctrine-must necessarily remain a wholly inadequate methodology for the conduct of the history of ideas.” (Skinner 1969, 31) 
reasoning: one is never to leave a piece of textual evidence on its own (e.g. the accusation of atheism by Calvin). "We have to restrain ourselves from using documents in isolation". (Febvre 1962, 32) Instead, Febvre relates any documents that could be used as evidence to other documents. In the case of the accusation by Calvin, Febvre brings along other texts to assess the significance of the accusation. He specifically points to similar textual accusations by Dolet, Henri Estienne, and notably Rabelais himself. (Febvre 1962, 129-134) Febvre, however, uses these to argue over the significance of these texts, and thus over what they are evidence of. He does not use them as justification for the reliability or unreliability of Calvin's accusation, as Kosso's framework would have it. Neither does he show, as Hurst's framework implies, how the description of Calvin's text as an accusation is (in)consistent with the descriptions of other similar texts. Whether the descriptions of these texts are inconsistent cannot be determined by the texts themselves. An external norm needs to assess this. And I argue that understanding is such a norm.

Both Kosso and Hurst argued that their coherentist models of textual evidence are forwardlooking: it is important that the consistent network can be expanded by actively looking out for new pieces of evidence. However, as I pointed out in the previous section, Febvre claims that uncovering more texts, and even more intimate testimonies would not prove to be more enlightening. The discovery of new texts in which Rabelais is accused of atheism cannot help in ascertaining what such texts are evidence of: of unbelief, as Lefranc would want it, or of religious controversy, as Febvre argues.

Fundamentally, the coherentist proposals suffer from the following problem. They transfer the constraining nature of textual evidence to the coherence with other texts. Texts, however, can never justify their own reading. In Febvre's case, the evidentiary significance of the accusation by Calvin cannot be justified by accusations of other religious controversists, because it is equally unclear what those other accusations are evidence of. Even if there were an accusation of atheism aimed at Rabelais by e.g. Luther, the significance of such an accusation could still be interpreted in several ways, even though Calvin also made such an accusation. In this sense the coherentist position is too weak: the mere coherence between texts, even the possible future coherence leaves historical reasoning through texts underdetermined, even though cases like Febvre's reasoning show that this can be avoided. The coherentist account thus breaks apart when the historian requires evidence about the texts themselves, specifically when the historian needs evidence of what texts are evidence of. And 
he cannot find this is in other pieces of textual evidence.

Febvre's evidentiary reasoning emphasizes that the significance of texts within the historical age needs to be assessed, before these texts can be used as evidence for or against a certain historical claim. Assessing the significance of a body of texts determines what those texts are evidence of, and this assessment is exactly what can be called the understanding of texts. Let us revisit the rival understandings of Calvin's accusation of atheism. Lefranc's thesis - that Rabelais was an atheist - is based on an understanding of what it means to be accused of atheism in the $16^{\text {th }}$ century. To be accused of atheism by a strong believer, according to Lefranc, is at least partly what it is to be considered a true atheist in the $16^{\text {th }}$ century. Such an understanding installs a norm and constitutes the empirical evidence of unbelief, namely all the documented accusations of atheism in the $16^{\text {th }}$ century. Febvre's rival understanding of what it means to be accused of atheism in $16^{\text {th }}$ century France does not yield this evidence. He defines an accusation, especially in the first half of the $16^{\text {th }}$ century, as being part of what it means to disagree with someone on religious matters. So Febvre's understanding yields the textual accusations as evidence of religious controversy between different actors.

How can one know which of the rival understandings of textual documents better constitutes religious reality of 16th century France? Not through some kind of direct empirical research (accruing more texts e.g.), since the understanding determines what the documents are empirical evidence of. Febvre answers this question by claiming that his understanding of texts is more in line with the mental tools of the era than Lefranc's. Febvre's understanding constitutes Calvin's text, the struggle of Erasmus and Luther against irrational beliefs, and Rabelais' writings within a shared religious controversy of the era. Lefranc's understanding of these texts breaks them apart, and sets out different rules of thinking for all of their authors. Thus, a non-empiricist coherentist position emerges: not the coherence between the texts themselves should be the prime goal, but coherence between the norms that constitute what historical object or event a text is evidence of. This search for and discussion about the appropriate norms that govern a body of texts can be labelled as the search and discussion over the understanding of texts. Understanding is thus an epistemic and indispensable procedure that determines what physical texts are evidence of. It is epistemic, because it constitutes how texts can be evidence for historical claims. It is also indispensable, because without the constitution of texts as evidence historians are faced with nothing but bare 
physical documents that have no bearing on historical claims about the past. ${ }^{6}$

\section{Understanding as Epistemic Category}

Understanding has been a controversial epistemic category in analytic philosophy of science. The most influential and also controversial account of understanding was given by Carl Hempel in an article on the use of general laws in historiography (Hempel 1942). ${ }^{7}$ Hempel is very clear on the nature of understanding or empathic understanding as he describes it. "It is essentially a heuristic device; its function is to suggest certain psychological hypotheses which might serve as explanatory principles in the case under consideration." ${ }^{8}$ (Hempel 1942, 44) The operation of understanding on Hempel's account will yield candidates for explanatory claims of the historical events through the imagination of the historian. The soundness of the intuitively generated claims can, however, only follow from an empirical confirmation (Hempel 1942, 45). In Hempel's reconstruction of the justificatory nature of historical explanations he separates the understanding of texts or sources on the one hand from the empirical verification or justification on the other hand. Although the heuristic procedure of understanding can generate various accounts, only empirical evidence can arbitrate which of those accounts is correct or empirically more adequate.

Hempel's heuristic notion of understanding fails to capture the indispensability of understanding within the evidentiary reasoning of historians. His framework entails a predicament in typical cases like Febvre's argument against Lefranc: by introducing a better understanding of $16^{\text {th }}$ century texts, the evidentiary nature of the texts changes, which leads

6 Hurst also emphasizes that historical data, without a proper description and its related hypothesis about some change in the past, is meaningless for the historian (Hurst 1981, 279). The understanding of texts, however, is not a direct hypothesis about some occurrence in the past which can be related to other empirical data, as Hurst's data-descriptions are. Understanding determines how an entire body of texts is related to some delineated period of the past. Thus, understanding as an epistemic procedure determines a much wider range than the single data-description of Hurst's model.

7 Hempel's paper is now considered by many to have led philosophy of history on a wrong track. "This approach was a deeply impoverished one, and handicapped from the start in its ability to pose genuinely important questions about the nature of history and historical knowledge.” (Little 2012, sec. 3.1) Also see (Roth 1999, 249)

8 Hempel restates this central claim also in later papers, see e.g. (Hempel 1965, 161, 257). Hempel's position on understanding is typical for the opposition to understanding in logical empiricism (Uebel 2010). 
Febvre to argue for different claims based on the same texts. Hempel's framework has no account of the understanding of a text that yields new evidence: evidence is exactly what must arbitrate between rival hypotheses that came out of rival understandings. Hempel's characterization of the relation between evidence and understanding thus turns into a contradiction: the very element that is subjective and in need of empirical justification namely understanding - brings about the specific evidence that is supposed to test it. Any exclusion of understanding from the use of textual evidence in historiography will have to face this issue. And a mere heuristic account simply fails to adequately deal with this problem.

That Hempel's model of verification for historiography is flawed because of the importance of understanding texts in the human sciences is not a new insight. The best-known argument for this weakness came from Charles Taylor's papers on interpretation in the human sciences (Taylor 1971; Taylor 1980). Taylor argued that the verificationist model of science could not be reconciled with a hermeneutic science. Because the latter moves in a circle from reading to reading and is only interested in making sense of a specific societal practice, it will never attain a verificationist procedure to fall back on (Taylor 1971, 46). The understanding that is achieved through a hermeneutic science cannot elaborate hypotheses that enable one to predict and verify (Taylor 1971, 48). Prediction and the possibility of empirically verifying a prediction rest on the possibility of relating a past and a future event under the same conceptual net. This, however, is exactly what a hermeneutic understanding does not allow: there is no justification for presupposing that various events can be understood through the same conceptual scheme. Conceptual innovation brings an alteration of human reality along with it (Taylor 1971, 49). Taylor's conclusions are quite radical: "We cannot measure such sciences against the requirement of a science of verification: we cannot judge them by their predictive capacity. We have to accept that they are founded on intuitions which all do not share, and what is worse that these intuitions are closely bound up with our fundamental options." ${ }^{9}$ (Taylor 1971, 51) If human understanding is indispensable in any science of human action, then one must sacrifice the norm of universal agreement free from interpretive dispute and the requirement of intersubjective consensus (Taylor 1980, 38).

Taylor's conclusion is to go die-hard hermeneutic and reject any possibility of evidentiary standards for the hermeneutic sciences: they are bound up with our self-understanding and

9 For a similar argument and conclusion one could also look at (Berlin 1960, 12-16). 
thus part of a never ending process of understanding one's position in the world. While Taylor adequately points out that understanding is an indispensable aspect of research in the humanities, he fails to clarify how understanding is intimately entwined with the rules of evidence that are specific to research in those sciences. He is very quick to deny any possibility of intersubjective consensus for the humanities due to their necessary use of the procedure of understanding. Through the case of Febvre's reasoning with $16^{\text {th }}$ century texts, however, I have shown that the indispensability of understanding should not entail the impossibility of actual evidentiary standards that lead to intersubjective consensus. Historians do really use texts as actual evidence that can justify a historical claim, even of a rather complex nature, such as "Rabelais was not an atheist".

The hermeneutic stance gives no specific role to texts as evidence. According to many philosophers of historiography, however, textual evidence plays an important epistemic function as that which constrains the possible narratives or theories that a historian can yield of an age, event, or person. In many defences of historiography against post-modern relativism the notion of historical evidence has been used as the only possible touchstone of the accounts of historians. Paul Roth has argued that empirical evidence needs to have some kind of function in the assessment of theories under consideration (Roth 2007, 272). Similarly, Avizier Tucker claimed that scientific historiography relies on some central cognitive values of the research community of historians, one of the most important among them being "respect for evidence that consists of cross-referenced documents and oral testimonies" (Tucker 2001, 53).

I have argued that understanding plays an indispensable, epistemic role as a norm that constitutes what a text is evidence of. Rival understandings produce rival bodies of evidence, and these rival understandings can only be assessed as they produce a maximally coherent set of rules of thinking in a historical era. The search for coherence between the rules of thinking that constitute the significance of a text, is, however, close to Taylor's hermeneutic stance. Contrary to Taylor, I have, however, emphasized that texts can be used as actual evidence in an intersubjectively accessible process of historical reasoning. Texts and their understanding are not entwined in an unbreakable circle: it is understanding that constitutes texts as evidence. If agreement is reached over the understanding of a specific set of texts, historians are warranted to use these as constraints over their historical claims. 
This positive reassessment of understanding within evidentiary reasoning can help the practice of historiography by making explicit where historians stop arguing through textual evidence and start arguing over what texts are evidence of. Such a distinction was already made explicit by Febvre in his book. The end of his first chapter was about the mental tools of the historical actors that we need to use to decide what a text can be evidence of (Febvre 1962, 139-142). Febvre in this chapter is making explicit how he changes what early $16^{\text {th }}$ century French accusations of atheism are evidence of. Ever since Febvre's book, historians have accepted that the texts that used to be regarded as evidence of Rabelais' unbelief no longer are such evidence (Gauna 1992, 26). Febvre's explicit argumentative procedure has in this way definitively advanced one aspect of $16^{\text {th }}$ century historiography. Making a shift in the understanding explicit can in this way yield insight into the reasons why certain seemingly evidentiary conflicts within the discipline of historiography cannot be solved by merely adding more evidence.

\section{References}

Berlin, Isaiah. 1960. History and Theory: The Concept of Scientific History. History and Theory 1: 1-31.

Febvre, Lucien. 1962. Le problème de l'incroyance au XVIe siecle : la religion de Rabelais. Paris: Albin Michel.

Febvre, - - 1985. The Problem of Unbelief in the Sixteenth Century: The Religion of Rabelais. Trans. Beatrice Gottlieb. Cambridge: Harvard University Press.

Forsyth, Donald W., and Hans Staden. 1985. Three Cheers for Hans Staden: The Case for Brazilian Cannibalism. Ethnohistory 32: 17-36.

Gauna, Max. 1992. Upwellings: First Expressions of Unbelief in the Printed Literature of the French Renaissance. Rutherford: Fairleigh Dickinson University Press.

Hempel, Carl. 1965. Aspects of Scientific Explanation and Other Essays in the Philosophy of Science. New York: The Free Press.

Hempel, - . 1942. The Function of General Laws in History. The Journal of Philosophy 39: 35-48.

Hurst, B. C. 1981. The Myth of Historical Evidence. History and Theory 20: 278-290.

Iggers, Georg G. 1997. Historiography in the Twentieth Century: From Scientific Objectivity to the Postmodern Challenge. Middletown: Wesleyan University Press.

Kelley, Donald R. 1984. Review of The Problem of Unbelief in the Sixteenth Century. The Religion of Rabelais. The Catholic Historical Review 70: 346-347. 
Kosso, Peter. 1993. Historical Evidence and Epistemic Justification: Thucydides as a Case Study. History and Theory 32: 1-13.

Little, Daniel. 2012. Philosophy of History. In The Stanford Encyclopedia of Philosophy, ed. Edward N. Zalta, Winter 2012.

Obeyesekere, Gananath. 1997. The apotheosis of Captain Cook: European mythmaking in the Pacific. Princeton University Press.

Roth, Paul A. 1999. The Full Hempel. History and Theory 38: 249-263.

Roth, - . 2007. The Disappearance of the Empirical: Some Reflections on Contemporary Culture Theory and Historiography. Journal of the Philosophy of History 1: 271-292.

Schmolz-Haberlein, Michaela, and Mark Haberlein. 2001. Hans Staden, Neil L. Whitehead, and the Cultural Politics of Scholarly Publishing. Hispanic American Historical Review 81: 745-751.

Skinner, Quentin. 1969. Meaning and Understanding in the History of Ideas. History and Theory 8: 3-53.

Taylor, Charles. 1971. Interpretation and the Sciences of Man. The Review of Metaphysics 25 (1): 3-51.

Taylor, - . 1980. Understanding in human science. The Review of Metaphysics 34 (1): 25-38.

Tucker, Aviezer. 2001. The Future of the Philosophy of Historiography. History and Theory 40: 37-56.

Uebel, Thomas. 2010. Opposition to Verstehen in Orthodox Logical Empiricism. In Historical Perspectives on Erklären and Verstehen, ed. Uljana Feest, 291-308. Dordrecht: Springer.

Whitehead, Neil L. 2000. Hans Staden and the Cultural Politics of Cannibalism. Hispanic American Historical Review 80: 721-751.

Wootton, David. 1988. Lucien Febvre and the problem of unbelief in the early modern period. The Journal of Modern History 60 (4): 695-730. 